\title{
Dynamics of customer interaction on social media platforms
}

\author{
Ulrike Baumöl $^{1}$ • Linda Hollebeek ${ }^{2} \cdot$ Reinhard Jung $^{3}$
}

Received: 30 May 2016 / Accepted: 30 May 2016 / Published online: 9 June 2016

(C) Institute of Applied Informatics at University of Leipzig 2016

Keywords Customer engagement $\cdot$ Customer interaction . Personalized interaction $\cdot$ Social media $\cdot$ Social CRM

JEL O33 $\cdot$ O35 $\cdot$ M15 $\cdot$ M31 $\cdot$ M39

The nature and dynamics of interactivity between consumers and organizations continue to evolve at a rapid pace (Ghazali et al. 2016). Specifically, while these interactions are gaining prominence in terms of marketing and customer relationship management, consumers are simultaneously gaining increasing influence in the online sphere (Malthouse et al. 2013; Kaplan and Haenlein 2010; De Vries et al. 2012). Contemporary consumers, for instance, are highly likely to consider product or brandrelated information provided by other consumers, rather than relying exclusively on marketing material (Hanna et al. 2011). At the same time, today's digital consumers expect their preferences to be center stage for the companies they choose to purchase from through collaborative, personalized interactions

Ulrike Baumöl

Ulrike.baumoel@fernuni-hagen.de

Linda Hollebeek

1.hollebeek@auckland.ac.nz

Reinhard Jung

Reinhard.Jung@unisg.ch

1 University of Hagen, Universitätsstrasse 42, DE-58097 Hagen, Germany

2 University of Auckland, Owen G Glenn Building, 12 Grafton Road, Auckland, New Zealand

3 Universit of St. Gallen, Unterer Graben 21, CH-9000 St. Gallen, Switzerland
(Munnukka and Järvi 2014; Greenberg 2010). It has thus become crucial for companies to create a superior consumer experience, which can be leveraged by fostering enhanced consumer engagement, and which, in turn, is expected to generate enhanced customer loyalty (Brodie et al. 2013).

Consumer needs for interactive, collaborative, and personalized interactions have been strongly influenced by the rapid proliferation of social media, which provide a new mode of communication and interaction, not only among consumers, but also between consumers and brands (Hollebeek et al. 2014; Sasser et al. 2014). Social media comprise a group of internet-based applications building on the concept of web 2.0 that encourage user connection, participation, and collaboration, and the sharing of content (Musser and O'Reilly 2007). Examples of social media include social networks (e.g., Facebook), (micro)blogs (e.g., Twitter), collaborative projects (e.g., Wikipedia), content communities (e.g., YouTube), virtual worlds (e.g., Second Life), and games (e.g., World of Warcraft; Kaplan and Haenlein 2010). Leading companies, including Google, have created extensive engagement platforms comprising services ranging from mobile apps (e.g., Google Play), to physical devices (e.g., Google Glass; Breidbach et al. 2014; Brodie et al. 2016). In addition, firms are increasingly turning to social commerce; that is, social media-enabled sales channels (Baethge et al. 2016).

Social media have transformed the nature and practice of online communication into an extensive, two-way dialog among users, which may cover private and/or social topics and issues, as well as about companies' products, brands and services (Lehmkuhl and Jung 2013). Networked consumers no longer merely act as passive recipients of product-, brandor firm-related information, but are enabled to create, modify and exchange their own, personalized content and applications through social media (Kaplan and Haenlein 2010; Hollebeek and Brodie 2016). 
The popularity of social media poses both risks and opportunities for organizations (Munnukka and Järvi 2014). On the one hand, an organization's reduced level of control over information about its products and brands bears the unavoidable risk of transparency (Kaplan and Haenlein 2010). Further, product-, brand- or firm-related conversations on social media may occur not only between a firm's current or past customers, but may also include 'non-paying customers' (Groeger et al. 2016); thus rendering an added level of complexity in social media-based interactions. On the other hand, the pervasiveness of social media provides companies with new ways of interacting with consumers (Sasser et al. 2014). Leveraging trust among consumers, and tracking consumers' willingly shared product or brand-related views has the potential to significantly enhance consumer communications and relationships (Malthouse et al. 2013; Hollebeek et al. 2016b). Many companies have recognized the effect of online conversations on consumer purchase decisions, and actively contribute to these. Overall, social media allow companies to connect with consumers, and communicate and share information with them. Social media thereby complement traditional 'push' communications (e.g., e-mail newsletters; Choudhury and Harrigan 2014) with multidirectional communication, thus facilitating dialogue with consumers, including current and prospective customers. The 'multi-directional' facet of social media communications refers to social media interactions not being limited to dialogue between the company and a focal consumer exclusively - but instead, this may extend to include other consumers (e.g., those in a focal consumer's network; Meng et al. 2016).

Based on the outlined social media hallmarks, engaging in conversations with consumers via social media has high potential for company-based customer relationship management (CRM; Malthouse et al. 2013). Specifically, by actively engaging users in company issues and business processes via social media, companies have the capability to tap into new opportunities to improve customer satisfaction and loyalty (Hollebeek et al. 2014). One important CRM facilitator is the acquisition and exploitation of consumer knowledge, enabled by the intelligent use of data and technology solutions, to create a superior consumer experience (Frow and Payne 2009; Lee et al. 2006). Through social media, companies have broad access to consumers' public and private information (e.g., user profiles, activities, interests, relationships, followers of a company's social media account), as well as consumers' networks of contacts (Reinhold and Alt 2012). Information regarding consumers' product-, brand- or firm-related opinions and views is expected to be conducive to revealing consumer needs and experiences (Alt and Reinhold 2012), which, in turn, can be useful for leveraging the development of customer relationships and increasing customer lifetime value (Kumar 2013; Kumar et al. 2010; Kumar and Pansari 2015).

The deployment of social media within CRM is a rising phenomenon, leading to a new paradigm referred to as Social CRM
(Trainor et al. 2014). Social CRM is a philosophy and business strategy that professionalizes the relationship to consumers using social media (Malthouse et al. 2013). Greenberg (2010: p. 413) defines Social CRM as "a philosophy and a business strategy, supported by a technology platform, business rules, processes and social characteristics, designed to engage the customer in a collaborative conversation in order to provide mutually beneficial value in a trusted \& transparent business environment."

Social CRM constitutes a consumer-centric management approach (Dutot 2013; Greenberg 2010) that takes into account that the customer relationship is no longer controlled by the company, but is based on interactions not only between the company and focal consumers, but also among consumers themselves (Choudhury and Harrigan 2014; Faase et al. 2011). The consumer is thus regarded as a collaborative partner within a consumer-centric environment (Greenberg 2010); thus leading to the rising importance of consumer- or customer cocreation (Vargo and Lusch 2016), and coproduction (Etgar 2008; Sawhney et al. 2005), which reflect consumer participation in organizational processes, resulting in mutual benefit for both parties (Choudhury and Harrigan 2014; Greenberg 2010).

Social CRM activities encompass, in their most basic form, the use of social media to publish advertisements that reach broad audiences for the purpose of improving marketing efficiency (Malthouse et al. 2013). Additionally, encouraging consumers to share positive user experiences via social media can lead to improved brand reputation and sales increases (e.g., by enticing fickle or indecisive consumers to purchase products or services; Kaplan and Haenlein 2010). Further, firms' leveraging of consumers' social networks generates the opportunity to gain relevant business insight (e.g., with respect to consumer preferences for particular product attributes, or the ways in which consumers use particular products; Tilly et al. 2015). These insights, in turn, can be deployed to enhance or leverage customer relationships, and to better align the firm's offerings with specific consumer needs (e.g., articulated customer requirements or complaints can be used in product or service innovation processes). Moreover, social media can be used to facilitate micro-segmentation; that is, the targeting of individual customer segments, and catering to their unique needs and preferences with personalized, customized offerings (Berthon et al. 2012).

Further opportunities arise from the integration of consumers into operational procedures via social media, including by reducing service costs (Chesbrough 2007). Since service demand on social media platforms has increased significantly over recent years, a growing number of companies is now adopting a service-oriented Social CRM approach (Trainor et al. 2014). In addition to providing timely responses to service requests on proprietary or third-party platforms, companies engage consumers in consumer-to-consumer support (Breidbach et al. 2014); thus reducing companies' service costs. Yet, not only companies benefit from social CRM. Consumers can also benefit from companies' social CRM 
activities, such as through relationship-based benefits, interaction and exchange, and enhanced capacity to exert influence on business activities and processes (Sawhney et al. 2005). Examples include product or service discounts, special (e.g., VIP customer) promotions, and accelerated fulfilment of customer support requests (Rosenberger et al. 2015).

In light of these recent developments and challenges, further research addressing the manifestations and dynamics of social media-based customer/company interactions is needed. Specifically, contemporary managers require enhanced insight, decision support and relevant research to inform their strategic decision-making in the area of social media marketing, the effects of the changing nature of such interactions and consumers' ensuing engagement on (inter)organizational strategies, processes, information technology (IT) infrastructure and organizational culture, as well as the identification, management and monitoring of associated organizational risks and opportunities.

This special issue comprises four papers that address specific issues with respect to the "Dynamics of Customer Interaction on Social Media Platforms" from a number of theoretical and empirical perspectives.

The paper by Schultz (2016) titled "Insights from Consumer Interactions on a Social Networking Site: Findings from Six Apparel Retail Brands" presents findings in the area of consumer reactions to both brand postings and consumer-initiated social interactions. The results are used to develop a framework, which allows companies to identify the interaction strategy of competitors, and draws relevant implications from these analyses.

In their paper "Consequence of Customer Engagement Behavior: When Negative Facebook Posts Have Positive Effects" by Bitter and Grabner-Kräuter (2016), by means of conducting experiments, investigate under which circumstances negative brand-related Facebook posts turn into unexpected, favorable effects. This paper, as such builds on pioneering work addressing customer engagement behaviors, and adopts a novel approach to this emerging concept.

The paper "The Low Status Advantage: The Effect of Status Structure on Participation in an Online Community" by Hanson and Jiang (2016) presents findings on the effects of members' status structure and consumption motivation within an online community on consumers' ensuing willingness to participate in the community.

In their paper titled "Generating and Exploiting Customer Insights from Social Media Data," Wieneke and Lehrer (2016) draw on seven case studies addressing companies' deployment of social media data. The research focuses on both the required absorptive capacity of companies and contingent factors, and concludes by drawing a set of theoretical and managerial implications arising from these analyses.

On a final note, we would like to sincerely thank our highly competent and supportive team of reviewers. Without diligent authors and reviewers we would not have been able to compile this Special Issue. We hope you will enjoy reading and using the work contained within this Issue.

Sincerely,

Ulrike Baumöl

Linda D. Hollebeek

Reinhard Jung

\section{References}

Alt, R., \& Reinhold, O. (2012). Social customer relationship management (social CRM) - application and technology. Business \& Information Systems Engineering, 54(5), 287-291.

Baethge, C., Klier, J. and Klier, M. 2016. Social commerce: state-of-theart and future research directions. Electronic Markets, In Press, doi: 10.1007/s12525-016-0225-2.

Berthon, P. R., Pitt, L. F., Plangger, K., \& Shapiro, D. (2012). Marketing meets web 2.0, social media, and creative consumers: implications for international marketing strategy. Business Horizons, 55(3), 261-271.

Bitter, S., \& Grabner-Kräuter, S. (2016). Consequence of Customer Engagement Behavior: When Negative Facebook Posts Have Positive Effects. Electronic Markets, 26(3), doi:10.1007/s12525016-0220-7.

Breidbach, C. F., Brodie, R., \& Hollebeek, L. (2014). Beyond virtuality: from engagement platforms to engagement ecosystems. Managing Service Quality, 24(6), 592-611.

Brodie, R. J., Ilic, A., Juric, B., \& Hollebeek, L. (2013). Consumer engagement in a virtual Brand Community: an exploratory analysis. Journal of Business Research, 66(1), 105-114.

Brodie, R. J., Conduit, J., \& Hollebeek, L. D. (2016). Customer engagement: contemporary issues and challenges. London: Routledge.

Chesbrough, H. (2007). Business model innovation: It's not just about technology anymore. Strategy \& Leadership, 35(6), 12-17.

Choudhury, M. M., \& Harrigan, P. (2014). CRM to social CRM: the integration of new technologies into customer relationship management. Journal of Strategic Marketing, 22(2), 149-176.

De Vries, L., Gensler, S., \& Leeflang, P. S. H. (2012). Popularity of brand posts on brand Fan pages: an investigation of the effects of social media marketing. Journal of Interactive Marketing, 26(2), 83-91.

Dutot, V. (2013). A new strategy for customer engagement: how do French firms use social CRM? International Business Research, $6(9), 54-67$.

Etgar, M. (2008). A descriptive model of the consumer Co-production process. Journal of the Academy of Marketing Science, 36(1), 97-108.

Faase, R., Helms, R., \& Spruit, M. (2011). Web 2.0 in the CRM domain: defining social CRM. International Journal of Electronic Customer Relationship Management, 5(1), 1-22.

Frow, P. E., \& Payne, A. F. (2009). Customer relationship management: a strategic perspective. Journal of Business Market Management, $3(1), 7-27$.

Ghazali, E., Nguyen, B., Mutum, D. S., \& Asraf Mohd-Any, A. (2016). Constructing online switching barriers: examining the effects of switching costs and alternative attractiveness on e-store loyalty in online pure-play retailers. Electronic Markets, 26(2), 157-171.

Greenberg, P. (2010). The impact of CRM 2.0 on customer insight. Journal of Business \& Industrial Marketing, 25(6), 410-419.

Groeger, L., Moroko, L., \& Hollebeek, L. (2016). Capturing value from non-paying consumers' engagement Behaviours: field evidence and 
development of a theoretical model. Journal of Strategic Marketing, 24(3-4), 190-209.

Hanna, R., Rohm, A., \& Crittenden, V. L. (2011). We're all connected: the power of the social media ecosystem. Business Horizons, 54(3), 265-273.

Hanson, S., \& Jiang, L. (2016). The Low Status Advantage: The Effect of Status Structure on Participation in an Online Community. Electronic Markets, 26(3), doi:10.1007/s12525-015-0200-3.

Hollebeek, L. D., \& Brodie, R. J. (2016). Non-monetary social and network value: understanding the effects of non-paying customers in new media. Journal of Strategic Marketing, 24(3-4), 169-174.

Hollebeek, L., Glynn, M. S., \& Brodie, R. J. (2014). Consumer brand engagement in social media: conceptualization, scale development and validation. Journal of Interactive Marketing, 28(2), 149-165.

Hollebeek, L. D., Conduit, J., Soutar, G., Sweeney, J., Karpen, I. O., Jarvis, W., et al. (2016b). Epilogue to the special issue and reflections on the future of engagement research. Journal of Marketing Management, 32(5-6), 586-594.

Kaplan, A. M., \& Haenlein, M. (2010). Users of the world, unite! The challenges and opportunities of social media. Business Horizons, 53(1), 59-68

Kumar, V. (2013). Profitable customer engagement: concept, metrics, and strategies. New Delhi: Sage Publications.

Kumar, V. and Pansari, A. 2015. Competitive advantage through engagement. Journal of Marketing Research, In Press, doi:10.1509/jmr.15.0044.

Kumar, V., Aksoy, L., Donkers, B., Venkatesan, R., Wiesel, T., \& Tillmanns, S. (2010). Undervalued or overvalued customers: capturing Total customer engagement value. Journal of Service Research, 13(3), 297-310.

Lee, M. K. O., Cheung, C. M. K., Lim, K. H., \& Sia, C. L. (2006). Understanding customer knowledge sharing in web-based discussion boards: an exploratory study. Internet Research, 16(3), 289-303.

Lehmkuhl, T., and Jung, R. 2013. Towards social CRM - scoping the concept and guiding research. Proceedings of the 26th Bled eConference, Bled, Slovenia, 190-205.

Malthouse, E. C., Haenlein, M., Skiera, B., Wege, E., \& Zhang, M. (2013). Managing customer relationships in the social media era: introducing the social CRM house. Journal of Interactive Marketing, 27(4), 270-280.
Meng, Q., Zhang, N., Zhao, X., Li, F., \& Guan, X. (2016). The governance strategies for public emergencies on social media and their effects: a case study on the microblog data. Electronic Markets, 26(1), 15-29.

Munnukka, J., \& Järvi, P. (2014). Perceived risks and risk Management of Social Media in an organizational context. Electronic Markets, 24(3), 219-229.

Musser, J., \& O'Reilly, T. (2007). Web 2.0 principles and best practices. Gravenstein: O'Reilly Media, Inc..

Reinhold, O., and Alt, R. 2012. Social customer relationship management: state of the art and learnings from current projects. Proceedings of the 25th Bled eConference, Bled, Slovenia, 155-169.

Rosenberger, M., Lehmkuhl, T., and Jung, R. 2015. Conceptualising and exploring user activities in social media. Proceedings of the 14th IFIP WG 6.11 Conference on e-Business, e-Services, and e-Society (I3E 2015), Delft, The Netherlands, 107-118.

Sasser, S., Kilgour, M., \& Hollebeek, L. D. (2014). Marketing in an interactive world: the evolving nature of communication processes using social media. In K. Lertwachera \& A. Ayanso (Eds.), Harnessing the Power of Social Media and Web Analytics: Techniques, Tools, and Applications (chapter 2) (pp. 29-52). New York: IGI Global.

Sawhney, M., Verona, G., \& Prandelli, E. (2005). Collaborating to create: the internet as a platform for customer engagement in product innovation. Journal of Interactive Marketing, 19(4), 4-17.

Schultz, C. (2016). Insights from Consumer Interactions on a Social Networking Site: Findings from Six Apparel Retail Brands. Electronic Markets, 26(3), doi:10.1007/s12525-015-0209-7.

Tilly, R., Fischbach, K., \& Schoder, D. (2015). Mineable or messy? Assessing the quality of macro-level tourism information derived from social media. Electronic Markets, 25(3), 227-241.

Trainor, K. J., Andzulis, J. M., Rapp, A., \& Agnihotri, R. (2014). Social media technology usage and customer relationship performance: a capabilities-based examination of social CRM. Journal of Business Research, 67(6), 1201-1208.

Vargo, S. L., \& Lusch, R. F. (2016). Institutions and axioms: an extension and update of service-dominant logic. Journal of the Academy of Marketing Science, 44(1), 5-23.

Wieneke, A. \& Lehrer, C. (2016). Generating and Exploiting Customer Insights from Social Media Data. Electronic Markets, 26(3), doi:10. 1007/s12525-016-0226-1. 